\title{
Urinary Infection in Two Selected Neonatal Populations
}

\author{
P. E. GOWER, P. HUSBAND, J. C. COLEMAN, and G. J. A. I. SNODGRASS \\ From Medical Research Council Renal Infection Group, and the Departments of Paediatrics and Bacteriology, Fulham \\ Hospital, London
}

Gower, P. E., Husband, P., Coleman, J. C., and Snodgrass, G. J. A. I. (1970). Archives of Disease in Childhood, 45, 259. Urinary infection in two selected neonatal populations. The urines from 204 infants admitted to a neonatal special care unit and from 25 infants whose mothers had bacteriuria in the last trimester of pregnancy were cultured and examined for white cells.

A comparison of 39 bag collected urines with suprapubic specimens showed that growth in a bag collection was usually due to contamination, and that the presence of more than $10 \mathrm{WBC} / \mathrm{cu} . \mathrm{mm}$. in the suprapubic aspirate was not usually associated with a positive culture.

Only 2 infants from a total of 70 studied in the special care unit had more than 100,000 organisms $/ \mathrm{ml}$. with more than $10 \mathrm{WBC} / \mathrm{cu} . \mathrm{mm}$. in the bladder urine. All urines, which were obtained from infants whose mothers had bacteriuria in the last trimester of pregnancy, were sterile. These results support the view that neonatal urinary infection is uncommon and that routine screening for bacteriuria among infants of this age is not justified.

Urinary tract infection in the neonatal period is often difficult to diagnose and if untreated carries a poor prognosis (Smallpeice, 1968). In infants it may result in renal scarring in adult life (Hodson and Wilson, 1965). The prevalence of neonatal urinary tract infection has been studied using a variety of techniques to collect the urine. Using a sterile bag for urine collection, Lincoln and Winberg (1964) found a prevalence as high as $35 \%$ in apparently healthy newborn males, though this figure was reduced to $10 \%$ by more adequate perineal cleansing. McCarthy and Pryles (1963) found a prevalence of $7 \%$ in normal infants when the urine was collected into a sterile test-tube. Recently, both Nelson and Peters (1965) and Newman, O'Neill, and Parker (1967) stressed the error introduced by contamination using a bag collection and showed that this could be eliminated by suprapubic aspiration of the bladder.

We report here a study of urinary infection in two selected neonatal populations. The first group consists of admissions to a premature baby and neonatal special care unit within the past 2 years.

Received 3 October 1969.

^Present address: Department of Paediatrics, Guy's Hospital, London S.E.1.
The second group consists of the infants of mothers who were known to have had bacteriuria in the last trimester of pregnancy. This latter study was prompted by the observation of Patrick (1967) that $24.7 \%$ of such infants have a significant bacteriuria.

\section{Material and Methods}

Neonatal Special Care Unit. All infants admitted to the neonatal special care unit from January 1967December 1968 were included in this study. The unit admits not only premature babies, but also any neonate who is thought to justify special observation and investigation.

At the beginning of the investigation, urine was collected from infants in the neonatal special care unit using a bag collection technique. The perineum was cleansed with $1: 10,000$ benzalkonium chloride and a 'Chironseal' Great Ormond Street pattern adhesive plastic bag attached. The urine was withdrawn as soon as possible after passage into the bag. More recently, in selected cases, suprapubic aspiration of the bladder has been undertaken after the method of Pryles (1965); in some of these infants the urine was also collected by the bag technique.

The indications for suprapubic aspiration of urine were either that the urine collected in a bag contained more than $10 \mathrm{WBC} / \mathrm{cu} . \mathrm{mm}$. or that the infant was so ill that it was necessary to obtain an uncontaminated specimen of urine without delay. 
Infants of mothers with bacteriuria in the last trimester of pregnancy. In this part of the study the urines of 690 women in the last trimester of pregnancy attending the antenatal clinic of Charing Cross Hospital were examined for bacteriuria using the method described by Little (1966). 30 women fulfilled the criteria of more than 100,000 organisms $/ \mathrm{ml}$. in 2 consecutive urine cultures and were included in this study. 10 developed symptoms and were then treated with an antibiotic. Between one and three days after delivery, suprapubic aspiration of the bladder was performed on 25 of the infants born to these 30 mothers. The mother's permission was obtained in every case.

In both studies urine samples were examined for the presence of bacteria and white cells within 2 hours of collection, or after storage at $4{ }^{\circ} \mathrm{C}$. for not more than 6 hours. Quantitative cultures were prepared by either a standard $(2 \mathrm{~mm}$.) loop or a pour-plate technique, and were read after 18 hours' incubation at $37^{\circ} \mathrm{C}$. White cells were counted in samples taken from uncentrifuged specimens using a modified Fuchs Rosenthal chamber.

\section{Results}

Urinary findings in infants from the neonatal special care unit. Bag collection-bacterial counts (Table I). There were 306 admissions to the special care unit during 1967-68. 278 urine cultures were obtained from 204 patients using a bag collection. 65 urine samples were sterile on culture but 47 of these urines were obtained from infants known to be receiving antibiotics. 134 urines showed a mixed culture of 2 or more organisms, only 22 of these specimens were obtained from infants receiving antibiotic therapy. There were 50 urines with more than 10,000 organisms $/ \mathrm{ml}$. of a single organism, 27 of these contained more than 100,000 organisms $/ \mathrm{ml}$.

Bag collection-white cell count (Table I). Of the 278 urines, 227 contained 10 or less white cells/cu. $\mathrm{mm}$. The remaining 51 urines contained more than $10 \mathrm{WBC} / \mathrm{cu} . \mathrm{mm}$.; but only 10 of these contained a pure growth of more than 10,000 organisms/ $\mathrm{ml}$. The incidence of pyuria was not significantly different between the two sexes.

TABLE I

Urinary Findings in Neonates using a Bag Collection

\begin{tabular}{|c|c|c|c|c|}
\hline \multirow{2}{*}{$\begin{array}{c}\text { Culture } \\
\text { Organism/ml. }\end{array}$} & \multicolumn{2}{|c|}{$\begin{array}{l}\text { White Blood } \\
\text { Cells/cu.mm. }\end{array}$} & \multirow{2}{*}{ Total } & \multirow{2}{*}{$\begin{array}{l}\text { No. Taking } \\
\text { Antibiotics }\end{array}$} \\
\hline & $<10$ & $>10$ & & \\
\hline $\begin{array}{l}\text { Nil } \\
<10,000 \\
10,000-100,000 \\
>100,000 \\
\text { Mixed }\end{array}$ & $\begin{array}{r}58 \\
24 \\
20 \\
20 \\
105\end{array}$ & $\begin{array}{r}7 \\
5 \\
3 \\
7 \\
29\end{array}$ & $\begin{array}{r}65 \\
29 \\
23 \\
27 \\
134\end{array}$ & $\begin{array}{r}47 \\
9 \\
6 \\
5 \\
22\end{array}$ \\
\hline
\end{tabular}

Suprapubic aspiration of bladder-bacterial counts (Tables II and III). 70 samples of urine werẹ. obtained by suprapubic aspiration of the bladde from 61 infants; 63 of these were sterile (Table II) 39 of the 70 urines collected from 38 infants were available for comparison with a corresponding bag홈. collected urine (Table III). The bag collection always preceded the bladder aspiration, the twळ collections were always less than 1 week aparten and none of the infants was receiving an antibiotic. 34 of the aspirated urines were sterile; only 5 showed any growth on culture; 2 contained mor than $100,000 / \mathrm{ml}$. Esch. coli, one mixed growth of Esch. coli and Strep. faecalis, one 10,000-100,000\% coagulase positive staphylococci and one less than 10,000 Esch. coli and micrococci. Repeat supract pubic aspiration on the latter 2 infants within week showed sterile urines, no antibiotics havin\& been given.

TABLE II

Urinary Findings in Neonates using a Suprapubic Aspiration

\begin{tabular}{|c|c|c|c|c|}
\hline \multirow{2}{*}{$\begin{array}{c}\text { Culture } \\
\text { Organisms } / \mathrm{ml} \text {. }\end{array}$} & \multicolumn{2}{|c|}{$\begin{array}{l}\text { White Blood } \\
\text { Cells/cu.mm. }\end{array}$} & \multirow{2}{*}{$\begin{array}{c}\text { Not } \\
\text { Counted }\end{array}$} & \multirow{2}{*}{ Total } \\
\hline & $<10$ & $>10$ & & \\
\hline $\begin{array}{l}\text { Nil } \\
<10,000 \\
10,000-100,000 \\
>100,000 \\
\text { Mixed }\end{array}$ & $\begin{array}{c}56 \\
\mathrm{Nil} \\
1 \\
\mathrm{Nil} \\
1\end{array}$ & $\begin{array}{c}5 \\
\text { Nil } \\
\text { Nil } \\
2 \\
\text { Nil }\end{array}$ & $\begin{array}{r}2 \\
\mathrm{Nil} \\
1 \\
1 \\
1\end{array}$ & $\begin{array}{c}63 \\
\text { Nil } \\
2 \\
3 \\
2\end{array}$ \\
\hline
\end{tabular}

TABLE III

Comparison of Bag-collected Urine with Suprapubic Aspirates of Bladder

\begin{tabular}{|c|c|c|c|c|c|}
\hline \multirow{2}{*}{$\begin{array}{l}\text { Bag Collection } \\
\text { Organisms/ml. }\end{array}$} & \multicolumn{5}{|c|}{ Suprapubic Aspiration Organisms/ml. } \\
\hline & Nil & $<10,000$ & $\begin{array}{c}10,000 \\
100,000\end{array}$ & $>100,000$ & Mixed \\
\hline $\begin{array}{l}<10,000 \\
10,000-100,000 \\
>100,000 \\
\text { Mixed }\end{array}$ & $\begin{array}{r}3 \\
5 \\
6 \\
20\end{array}$ & $\bar{z}$ & $\frac{-}{1}$ & $\begin{array}{l}-1 \\
1 \\
-\end{array}$ & $\begin{array}{l}- \text { 음 } \\
-\frac{I}{2} \\
2\end{array}$ \\
\hline
\end{tabular}

Of the remaining 31 urines, 7 were taken fror infants on antibiotics, 3 were from infants in whorfo the bladder aspiration preceded the bag collection? 18 were taken from infants without a bag collectioms and in 3 the two collections were more than 1 weet apart. 29 of these urines were sterile, of the othes 2,1 showed a growth of $10,000-100,000 / \mathrm{m}$ ए Esch. coli; and 1 more than $100,000 / \mathrm{ml}$. Esch. col and Strep. faecalis. 
Suprapubic aspiration of bladder-white cell counts (Tables II and IV). White cell counts were carried out in 65 of 70 suprapubic aspirations; only 7 contained more than $10 \mathrm{WBC} /$ cu.mm. (Table II). Of the 39 urines available for comparison of a bag collection with a suprapubic aspiration (Table IV), 4 contained more than $10 \mathrm{WBC} / \mathrm{cu} . \mathrm{mm} ., 30$ less than $10 \mathrm{WBC} / \mathrm{cu} . \mathrm{mm}$., and 5 were not counted. Of the other 31 urines collected by suprapubic aspiration, 3 contained more than $10 \mathrm{WBC} / \mathrm{cu} . \mathrm{mm}$. and 28 less than $10 \mathrm{WBC} / \mathrm{cu} . \mathrm{mm}$.

\section{TABLE IV}

WBC Analysis of Suprapubic Aspiration Compared to Corresponding Bag Collection

\begin{tabular}{|c|c|c|c|c|}
\hline \multirow{2}{*}{$\begin{array}{c}\text { Bag } \\
\text { Urine } \\
\text { WBC/cu.mm. }\end{array}$} & \multicolumn{4}{|c|}{ Suprapubic Aspiration (WBC/cu.mm.) } \\
\hline & Nil & $<10$ & $>10$ & Not Counted \\
\hline $\begin{array}{l}\text { Nil } \\
<10 \\
>10 \\
\text { Not counted }\end{array}$ & $\begin{array}{r}7 \\
3 \\
2 \\
-\end{array}$ & $\begin{array}{l}2 \\
5 \\
9 \\
2\end{array}$ & $\frac{1}{3}$ & $\frac{1}{1}$ \\
\hline
\end{tabular}

Correlation between white blood cells and organisms from bag collected specimens and suprapubic aspiration. In that group of 39 bag-collected urines available for comparison with a suprapubic aspiration there were 14 which contained more than $10 \mathrm{WBC} / \mathrm{cu}$. $\mathrm{mm}$. Only 3 of the corresponding suprapubic aspirations contained more than $10 \mathrm{WBC} / \mathrm{cu} . \mathrm{mm}$., and only 1 of these had an infected urine.

Urinary findings in infants of mothers with bacteriuria of pregnancy. In none of these was the urine collected with a bag. 30 of the 690 women who were screened for bacteriuria in the last trimester of pregnancy had more than 100,000 organisms $/ \mathrm{ml}$. in 2 consecutive urine cultures, an incidence of $4.4 \% .10$ became symptomatic and were treated with a short course of a sulphonamide or ampicillin; no difficulty was found in eradicating the bacteriuria and none relapsed later in pregnancy. A sample of urine was collected between the first and third postnatal day by suprapubic aspiration from 25 of the infants whose mothers had bacteriuria during pregnancy. The urine from all 25 infants was sterile on culture. 5 contained more than $10 \mathrm{WBC} / \mathrm{cu} . \mathrm{mm}$., all from infants whose mothers had asymptomatic bacteriuria persisting to term. The mean weight of the infants was $3 \cdot 7 \mathrm{~kg}$. None weighed less than $2.5 \mathrm{~kg}$. or showed any congenital abnormality in the early postnatal period.

\section{Discussion}

The value of suprapubic aspiration is illustrated in the following two cases.

Case 1. A male infant aged 3 days, birthweight $3.2 \mathrm{~kg}$. was admitted to the special care unit with vomiting and poor feeding. A bag-collected specimen of urine contained more than $50 \mathrm{WBC} / \mathrm{cu} . \mathrm{mm}$. with a pure growth of more than $100,000 / \mathrm{ml}$. Strep. faecalis. A suprapubic aspiration of urine on the same day showed only $8 \mathrm{WBC} / \mathrm{cu} . \mathrm{mm}$. and was sterile on culture. Feeding improved within a few days without any antibiotics being given.

Case 2. A male infant, birthweight $3.5 \mathrm{~kg}$. was admitted with severe cerebral irritation following a Ventouse extraction. The blood urea was found to be $80 \mathrm{mg} . / 100 \mathrm{ml}$. on the 4th day of life, and a suprapubic aspiration of urine showed between 10,000 and $100,000 / \mathrm{ml}$. Esch. coli. After treatment for 6 days with ampicillin a bag specimen contained more than 500 WBC/cu.mm. and a growth of more than $100,000 / \mathrm{ml}$. Esch. coli. Suprapubic aspiration of urine on the same day revealed more than $100 \mathrm{WBC} / \mathrm{cu} . \mathrm{mm}$. and a growth of more than $100,000 / \mathrm{ml}$. Esch. coli. resistant to ampicillin. After treatment with kanamycin and nitrofurantoin for two weeks a further suprapubic aspiration was sterile and contained no white cells. The blood urea returned to normal and an intravenous pyelogram showed no abnormality.

This report emphasizes the difficulty in diagnosing urinary tract infections in the neonatal period using a bag for urine collection. Only $10 \%$ of 70 selected suprapubic aspirations showed any growth on culture compared with $76.7 \%$ when a bag collection is used. Sterile urines were found in 65 bag-collected specimens, but $47(76 \%)$ were taken from infants on antibiotics. 14 of the 39 bag-collected urines available for comparison with a suprapubic aspiration contained more than 10 WBC/cu.mm.; only 2 of these showed a positive culture in the suprapubic aspirate. Of the 278 bag-collected urines that were obtained from infants not taking antibiotics, there were only 9 that were sterile and contained less than $10 \mathrm{WBC} / \mathrm{cu} . \mathrm{mm}$. We conclude that in a bag collection a positive urine culture is usually due to contamination, that a sterile urine culture often results from the presence of an antibiotic and that the presence of more than 10 white cells/cu.mm. with a pure growth of more than 100,000 organisms $/ \mathrm{ml}$. is not invariably associated with an infected bladder urine. It is clear, therefore, that bag-collected urines should not be used for the diagnosis of urinary tract infection in the neonatal period.

Two other techniques of urine collection have 
been described to overcome the difficulty of contamination of bag collection in the neonatal period. Boehm and Haynes (1966) found that infants will urinate on exciting the Perez reflex, and a mid-stream urine specimen may thus be obtained. However, in their series of newborn infants only 25 out of 55 urines were sterile though repeat collections would probably have increased the numbers of sterile specimens. O'Brien et al. (1968) used a clean catch technique whereby mid-stream urines were collected following bladder massage. They found the prevalence of bacteriuria in 300 neonates to be $1.6 \%$ on initial screening, but this was reduced to $0.3 \%$ when a second urine specimen was cultured.

Both of these methods may be used in epidemiological surveys but suffer from the disadvantage that repeat specimens have to be obtained for confirmation. Suprapubic aspiration has the advantage of obtaining bladder urine direct without the need for confirmatory specimens. It is free from serious complications (Pryles, 1965; Nelson and Peters, 1965; Newman et al., 1967), though gross haematuria persisting up to 24 hours after aspiration was noted by Saccharow and Pryles (1969) in 3 cases from a series of 654 infants and children, and perforation of abdominal viscera was described by Weathers and Wenzl (1969) in 3 infants where the viscera were pathologically enlarged.

Patrick (1967) reported that $24 \cdot 7 \%$ of infants whose mothers had untreated bacteriuria of pregnancy had a 'significant' coliform bacteriuria (more than 100,000 organisms $/ \mathrm{ml}$.) in bag-collected specimens. The incidence was $17.9 \%$ in infants of treated bacteriuric mothers and nil in infants of mothers with sterile urine. In addition, in women who had bacteriuria beyond 37 weeks, 4 out of 8 specimens of amniotic fluid showed coliform bacteria in Gram-stained smears, and 6 out of 19 grew Esch. coli in cord blood. In contrast, specimens of amniotic fluid and cord blood were sterile when taken from women with a sterile urine. These findings suggested that infection of the amniotic fluid with fetal bacteraemia and urinary tract infection may result from maternal bacteriuria particularly if left untreated. If this finding is accepted it would give added incentive for screening antenatal patients for bacteriuria.

The present study shows that all 25 infants born to mothers who had bacteriuria in the last trimester of pregnancy had sterile bladder urine 1-3 days after delivery. 17 of these mothers had untreated bacteriuria persisting to term. The average weight of the infants was $3.7 \mathrm{~kg}$. and none weighed less than $2.5 \mathrm{~kg}$. It is concluded, therefore, that routine screening of such infants for? urinary infection is not justified.

It is difficult to comment on the prevalence of bacteriuria among the neonatal population studied. Urines were not obtained from all infants, and $\overline{\bar{\omega}}$. other infants were treated with antibiotics either $\vec{\nabla}$ prophylactically or for some other infection. $\varrho$ Nevertheless there were only 2 out of 70 infants 5 whose bladder urine grew more than $100,000 \vec{\circ}$ organisms $/ \mathrm{ml}$. and contained more than $10 \mathrm{WBC} / \overrightarrow{-}$ cu.mm. This finding, together with the observa- $\vec{\sigma}$ tion that no infants born to bacteriuric mothers had an infected urine, suggests that neonatal urinary infections are uncommon. Yet many of specimens were obtained from infants who were $\sim$ unwell, and might be expected to show a higher $\hat{O}$ incidence of urinary tract infection than the neo- $N$ natal population in general. These results do not 0 support Stansfield's (1966) view that many urinary infections originate in the first month of life or maystart in utero. We believe that urinary tract $\frac{D}{0}$ infections in premature and neonatal infants are rare. This view is supported by the findings of $\overrightarrow{0}$ O'Brien et al. (1968) and MacGregor and Freeman (1968). This suggests that radiological pyelonephritic scarring with reflux probably originates in the first few years of life but not in the first month. Screening of infants routinely in the neonatalo period does not seem to be rewarding in revealing $\frac{\mathscr{Q}}{\bar{Q}}$ those children who will eventually develop severe $\varrho$ radiological pyelonephritic scarring with the atten- $\overrightarrow{\overrightarrow{0}}$ dant poor prognosis in adult life. It seems more important to screen older children for urinary tract infection in order to detect major renal radiological abnormalities (Kunin, Deutscher, and Paquin, 1964; Savage et al., 1969; Meadow, White? and Johnson, 1969).

We thank Dr. Hugh Jolly, Dr. H. Barrie, Professor N. Morris, and Mr. P. Curzen for allowing us too study their patients, Professor H. E. de Wardener and Professor $\mathrm{H}$. Winner for their advice and criticisms ; and the staff of the Bacteriology Department, Fulham Hospital, Mrs. B. Haswell and Mrs. L. Trappitt, for their technical assistance. The funds for the buildingo in which part of this work was carried out were supplied by Cerebos Ltd. and the Ockley Brick Works. N

REPERENCES

Boehm, J. J., and Haynes, J. L. (1966). Bacteriology of 'midstreame catch' urines. American fournal of Diseases of Children, 111 s 366.

Hodson, C. J., and Wilson, S. (1965). Natural history of chronic pyelonephritic scarring. British Medical fournal, 2, 191.

Kunin, C. M., Deutscher, R., and Paquin, A., Jr. (1964). Urinary tract infection in school children: an epidemiologic, clinical and? laboratory study. Medicine, 43, 91. 
Lincoln, K., and Winberg, J. (1964). Studies of urinary tract infections in infancy and childhood. II. Quantitative estimation of bacteriuria in unselected neonates with special reference to the occurrence of asymptomatic infections. Acta Paediatrica, 53, 307.

Little, P. J. (1966). The incidence of urinary infection in 5000 pregnant women. Lancet, 2, 925.

McCarthy, J. M., and Pryles, C. V. (1963). Clean voided and catheter neonatal urine specimens. American fournal of Diseases of Children, 106, 473.

MacGregor, M., and Freeman, P. (1968). Subclassification of childhood urinary tract infections as an aid to prognosis. In Urinary Tract Infection, p. 95 . Ed. by F. O'Grady and W. Brumfitt. Oxford University Press, London.

Meadow, S. R., White, R. H. R., and Johnson, N. M. (1969). Prevalence of symptomless urinary tract disease in Birmingham schoolchildren. 1. Pyuria and bacteriuria. British Medical Fournal, 3, 81.

Nelson, J. D., and Peters, P. C. (1965). Suprapubic aspiration of urine in premature and term infants. Pediatrics, 36, 132.

Newman, C. G. H., O'Neill, P., and Parker, A. (1967). Pyuria in infancy and the role of suprapubic aspiration of urine in the diagnosis of infection of the urinary tract. British Medical Fournal, 2, 277.

O'Brien, N. G., Carroll, R., Donovan, D. E., and Dundon, S. P. (1968). Bacteriuria and leucocyte excretion in the newborn. Fournal of the Irish Medical Association, 61, 267.
Patrick, M. J. (1967). Influence of maternal renal infection on the foetus and infant. Archives of Disease in Childhood, 42, 208.

Pryles, C. V. (1965). Percutaneous bladder aspiration and other methods of urine collection for bacteriologic study. Pediatrics, 36, 128.

Saccharow, L., and Pryles, C. V. (1969). Further experience with the use of percutaneous suprapubic aspiration of the urinary bladder. Bacteriologic studies in 654 infants and children. Pediatrics, 43, 1018.

Savage, D. C. L., Wilson, M. I., Ross, E. M., and Fee, W. M. (1969). Asymptomatic bacteriuria in girl entrants to Dundee primary schools. British Medical fournal, 3, 75.

Smallpeice, V. (1968). Urinary Tract Infection in Childhood and its Relevance to Disease in Adult Life. p. 134. Heinemann, London.

Stansfield, J. M. (1966). Clinical observation relating to incidence and aetiology of urinary-tract infections in children. British Medical fournal, 1, 631.

Weathers, W. T., and Wenzl, J. E. (1969). Suprapubic aspiration of the bladder. Perforation of a viscus other than the bladder. American Fournal of Diseases in Children, 117, 590.

Correspondence to Dr. P. E. Gower, Department of Medicine, Fulham Hospital, London W.6. 